\section{Implications of Transmigration Program Implementation Towards Transmigrant Welfare Levels}

\author{
Febriansyah*, Irwan Natakesuma \\ STIE GICI Business School, Universitas Sang Bumi Ruwa Jurai, \\ Lampung, Indonesia
}

\begin{abstract}
This study aims to determine the factors contributing to the transmigration program to the welfare level of transmigrants and compare aspects of the development of the welfare level of transmigrants at transmigration locations from before and after people become transmigrants. The research was conducted at the Transmigration location, Fajar Baru Village, Panca Jaya District, Mesuji Regency. The method used is quantitative, using questionnaires and document searches that are relevant to the research topic. The results showed that transmigrants were still categorized as poor or underprivileged. Some of the things that cause this situation include: First, the transmigrants do not have permanent jobs and only rely on work as farmers; and Second, the rice fields they own still have not produced anything, because the harvest period has not yet entered so that many transmigrants change professions to become casual workers. Practical implications can be done by carrying out more effective coaching by paying attention to the economic, socio-cultural, and mental-spiritual fields.
\end{abstract}

\section{Keywords:}

Local transmigration, farmer welfare, poverty alleviation.

\section{Corresponding Author:}

Febriansyah, STIE GICI Business School

West Java, Indonesia

Email: febriansyahali9@gmail.com

(c) The Author(s) 2021

DOI: https:// doi.org/ 10.36407/jmsab.v4i1.298

\section{(c) (1)}

CC BY: This license allows reusers to distribute, remix, adapt, and build upon the material in any medium or format, so long as attribution is given to the creator. The license allows for commercial use.

\section{Research Paper}

Management

Received: 10 Feb 2021

Accepted: 05 Jun 2021

Online: 30 Jun 2021

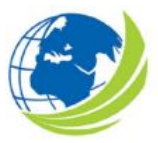

Jurnal Manajemen Strategi dan Aplikasi Bisnis, Vol 4, No. 1, 2021, pp. 189 - 198

eISSN 2655-237X 


\section{INTRODUCTION}

According to Law no. 29 of 2009, transmigration is a voluntary population movement from one area to another organized by the government to create new communities to assist the development of both visited and disadvantaged areas and support national development. The government classifies the types of transmigration into three groups: First, general transmigration, namely transmigration whose costs are entirely borne by the government; Second, independent transmigration, namely transmigration carried out by residents with some of the costs but still regulated by the government; and third, local transmigration, namely mass population movement from one area to another that is still in the development stage the same provincial government, and the costs are borne by the transmigration office (Arman, 2006).

Among the three types of transmigration above, local transmigration is a population movement that is quite burdensome for transmigrants, and this is because the division of land parcels in the new area is relatively too small. This has resulted in the transmigrants being landless and earning a living by cultivating other people's land. In addition, the lack of soil fertility in non-irrigated areas causes a decrease in the harvest time for transmigrants. According to Martono (1986) in Sutanto, Aruan, and Amir (2019), when viewed demographically, transmigration is seen as an effort to achieve balance in population distribution, also intended to create an expansion of job opportunities. So that the transmigration policy is directed at three main things, namely: First, transmigration plays a role in alleviating poverty caused by the powerlessness of the population to obtain a decent place to live; Second, providing business opportunities and job opportunities to the community; and Third, facilitating the community to move people and supporting the empowerment of the potential of regional, regional and location resources that have not been fully utilized so that they can develop more productively.

The transmigration paradigm does not only move people from densely populated areas to areas that are still underpopulated. More than that, transmigration is one way for the community to improve welfare and build food security (Suparno, 2007 in Putra, Hasan, Safitri, 2019). The national transmigration system with a new paradigm is based on five main points, namely: First, the development of transmigration as an effort to manage space and people, directed at supporting food security and the needs of the national council; Second, business development and cultivation in transmigration settlements are directed to support alternative energy policies by developing bio-energy crops such as oil palm, corn, sugar cane, cassava, and also Jatropha; Third, the development of transmigration settlements is directed at the development of border areas, outer islands, underdeveloped and isolated areas and seeks to reduce disparities between regions as part of efforts to support national resilience; Fourth, transmigration development as an effort to develop new regions needs to be done collaboratively with the private sector to develop investment so that transmigration is able to support investment equity, and; Fifth, the development of transmigration as one of the efforts to provide a place to live, a place to work, and a place of business which is one of the national strategies in overcoming unemployment and poverty as well as improving community welfare in a sustainable manner.

Based on the above background, this study has several objectives, namely: First, to determine the factors that contribute to the transmigration program to the level of welfare of 
Febriansyah \& Irwan Natakesuma

Local transmigration, farmer welfare, poverty alleviation

transmigrants; and Second, it aims to compare aspects of the development of the welfare level of transmigrants in transmigration locations from before and after people become transmigrants at transmigration locations in Mesuji Regency.

\section{METHODS}

The research was conducted in Fajar Baru Village, Panca Jaya District, Mesuji Regency. The quantitative method is collected through questionnaires and searching documents relevant to the research topic obtained from the Mesuji Regency Manpower and Transmigration Office.

\section{RESULTSAND DISCUSSION}

\section{Transmigrant Welfare Level}

The transmigration program at UPT Fajar Baru Mesuji has been started since 1983. The UPT was built on an area of 4000 hectares belonging to Kampung Fajar Baru and is located in the southern part of Kampung Adiluhur and Adimulyo while the east and west areas are bordered by Kampung Mekar Sari and Sungai Serdang Pecah. The transmigration program at UPT Fajar Baru Mesuji combines different types of transmigrants with different cultural backgrounds. Even though they consist of various cultural backgrounds, the fusion of people at UPT Fajar Baru Mesuji runs harmoniously because the transmigrants feel the same fate. In addition, justice is received equitably since the beginning of the entry of transmigrants at the transmigration location. While being a transmigration community, transmigrants are fostered in the transmigration village development program. It aims to improve the social, economic, and cultural life of the community. The transmigrants are expected to meet all the necessities of life, including clothing, food, and shelter. In addition, the program aims to overcome poverty, labor shortages, and the opening of new agricultural lands to utilize natural resources.

The government's policy in carrying out this transmigration program is to reduce poverty and encourage people to live prosperously. Rusli and Said (2012) assess poverty with the ability to meet the needs of life-based on poverty classification: First, too poor, namely areas whose per capita income is below 75\% of the population's minimum living needs. Needs; Second, poor, namely areas where the per capita income of the population is less than $25 \%$ or right on the "poverty line" or $25 \%$ right on the minimum living needs; Third, near-poor, are areas where the per capita income of the population is $25 \%$ more than the minimum living needs up to secondary markets (200\%); and fourth, non-poor, i.e., areas where the income per capita of the population exceeds the basic needs of secondary life.

\section{Table 1.}

Cost of Transmigration Residents

\begin{tabular}{lll}
\hline Classification of needs & Qty. & Description \\
\hline Cost of the meal & Rp. 22.590 .000 & Eat/ month \\
Transportation costs & Rp. 16.680 .000 & Cost of buying gasoline/ month \\
The cost of other needs & Rp. 4.470.000 & Purchase of kitchen utensils, toiletries, etc. \\
Total Cost Required & Rp 43.740.000 & \\
\hline
\end{tabular}

However, this assessment is only used as a benchmark to determine whether the transmigration residents at the UPT Fajar Baru location are said to be prosperous or not. The data used is data on 
Jurnal Manajemen Strategi dan Aplikasi Bisnis, Volume 4, Nomor. 1, 2021. 189 - 198

the overall income of transmigration residents deducted by the total expenditure in one month. This aims to summarize the level of welfare of the transmigrants. More detailed calculations can be seen in Table 1.

To see how significant the percentage of income is above the expenditure of the transmigration community, it can be seen in Table 2 below. Based on the calculations in the table, the residents of UPT Fajar Baru are still classified as poor people. Still, here the percentage figures almost show that residents can be classified as nearly inferior because the percentage figure reaches $21.89 \%$.

Table 2.

The percentage of poverty

\begin{tabular}{lll}
\hline Total Revenue & Total Expenditure & Percentage (\%) \\
\hline Rp. 56.000 .000 & Rp. 43.740 .000 & $21.89 \%$ \\
\hline
\end{tabular}

In terms of employment opportunities, the position of transmigrants in the near-poor classification is primarily influenced by the condition that the harvest period has not yet entered the rice fields. This causes transmigrants to switch professions as casual workers to fulfill their daily needs. Although the working conditions of the transmigrants are not fixed by being casual workers, the transmigrants are still in the category of being able to fulfill their daily lives. This is supported by other facts, such as the perfect physical building with adequate home lighting, namely electricity. The existence of defecation facilities in every place, and from other things such as kitchen activities already use gas. Then the situation that shows that the transmigrants have improved their standard of living can be seen from the tertiary assets they have, such as motorcycles and other electronic goods.

\section{Factors Affecting Welfare Levels of Transmigration Residents}

Income is an essential factor in the welfare of transmigrants. This is because it describes the efforts to fulfill the various needs of the transmigrants' lives at UPT Fajar Baru. Population income is measured by how much transmigrants can earn monthly, classified as low, medium, and high income. The low income earned is below the average income for transmigrants, which is Rp. $1,082,222-$. To see the categorization of the income level of transmigrants, see Table 3. Below:

Table 3.

Income Level of Transmigration Residents

\begin{tabular}{lll}
\hline Income level & Total population & Percentage (\%) \\
\hline Low Income & 18 & 40 \\
Medium Income & 20 & 44.4 \\
High Income & 7 & 15,6 \\
Total population & 45 & 100 \\
\hline
\end{tabular}

Measurements are carried out as follows: First, the mean income is seen from the accumulation of all income earned by residents and then averaged divided by the number of households; Second, the categorization of income is based on the income generated by all respondents divided by the number of respondents in the last month; Third, the number of residents here is a categorized sample; and Fourth, the percentage (\%) is obtained from the number of categorized citizens 


\section{Febriansyah \& Irwan Natakesuma}

Local transmigration, farmer welfare, poverty alleviation

divided by the number of samples. Judging from the income class division of transmigration residents, most are in the low and middle classes, namely $40 \%$ and $44.4 \%$, while those with high income tend to be less, namely, only $15.6 \%$.

The calculation of the Spearman correlation also shows that there is a relationship between income and the welfare of transmigrants. The result of the calculation of the Spearman correlation is 0.536 , or in this case, it can be said to be quite strong. This means that the relationship between the level of income and the level of welfare is positive. The higher the income level of transmigrants, the higher the level of welfare. The correlation between income level and welfare level is significant because the probability number or Sig. of 0.000 well below 0.05 . This shows that there is a relationship, or the level of welfare is influenced by income level.

\section{Contributing Factors of the Transmigration Program to the Welfare of Transmigrants}

Social Institution

The institutional system at UPT Fajar Baru is defined as the rules that apply among transmigrants and are related to the Indonesian cultural value system. According to Koentjaraningrat, (2004) in Pradana, (2018) there are four concepts of Indonesian cultural values: humans cannot live alone, depend on others, maintain good relations, and do the same in society. Referring to these four concepts, in developing the UPT, it is necessary to have the closeness of residents as transmigrant communities and farming communities so that the development and development of the UPT can be carried out together. The situation at the transmigration site shows that in the process of unifying residents towards the construction and construction of the UPT it is not difficult to do because the transmigrants are aware of their responsibilities and life goals in the UPT.

Health

Health is one of the benchmarks for the success of the transmigration program (Tjiptoherijanto, 1986 in Zulhilmi, M., \& Maulana, H. 2018). The health conditions of the transmigrants also affect the quality of life of the transmigrants themselves. Therefore, improving the health level of transmigrants will show the value of the quality of life and the success of the transmigration program.

Table 4.

Residents' Health Complaints

\begin{tabular}{lll}
\hline & Frequency & Percent \\
\hline Yes & 17 & 37,8 \\
No & 28 & 62,2 \\
Total & 45 & 100 \\
\hline
\end{tabular}

Table 4. above describes the health conditions at UPT Fajar Baru. It can be seen that there are still residents who are in the unhealthy category. Such conditions are very likely to occur in a UPT location.

This is due to the poor condition of health facilities at the Fajar Baru Village UPT, in the sense that they are not complete with the existing health infrastructure in the city, making it difficult for residents to take advantage of innovations in the health sector. Nevertheless, residents still maintain their health armed with the knowledge gained from the assistance that is held every month. 


\section{Table 5.}

Treatment frequency in past month

\begin{tabular}{ccc}
\hline & Frequency & Percent \\
0 & 29 & 64,4 \\
$<2$ times & 9 & 20,0 \\
2 times & 4 & 8,9 \\
$>2$ times & 3 & 6,7 \\
Total & 45 & 100 \\
\hline
\end{tabular}

Table 5 shows that 16 of the 17 residents who were sick immediately received treatment. This is because, in addition to gaining knowledge about maintaining health, at the location of UPT Fajar Baru, midwives are also placed by the Mesuji Regency government and the Transmigration Service. It aims to maintain the survival of the population and improve the health of citizens.

\section{Safety}

In addition to health factors, the safe conditions of the UPT can make transmigrants feel at home to live (Tjiptoherijanto, 1986 in Amitasari et al., 2021). The intensity of security and crime in a UPT is difficult to know and measure with certainty. However, the maximum UPT security condition can be seen in the overall success of the program with some reliable information as a security value. For example, low or no residents feel physically ill, no residents feel they have lost their belongings, no residents feel depressed, and the absence of the right of transmigrants to be taken by force is information that the UPT is a safe place to live. feel unsafe living in UPT will leave UPT. For this reason, the safety of residents living in the UPT must be considered. The security situation of the UPT Fajar Baru location can be said to be safe because all residents participate in maintaining security, especially at night; every night, citizens take turns patrolling to avoid criminal acts.

Independence

According to Sumodiningrat, 1999 in Yusup et al., 2015), there are three independent categories: material independence, intellectual independence, and management independence. Material independence is a productive ability to meet basic needs in times of crisis. Intellectual independence is forming a knowledge base that allows them to overcome forms of domination from outsiders. Finally, management independence is the ability to develop oneself and carry out and manage collective activities. The independence of the transmigrants at the Fajar Baru Village UPT can be seen from the transmigrants no longer relying on the assistance of clothing and boards by the government which is only given in the first year. In addition, there are efforts to develop houses, to procure household goods such as gas stoves, cabinets, chairs, and other household items which were not provided for initial placement, as well as efforts to expand the yard. This independence can also be used as a benchmark to determine the welfare of the transmigrants at the Fajar Baru Village UPT. 
Febriansyah \& Irwan Natakesuma

Local transmigration, farmer welfare, poverty alleviation

\section{Factors Affecting the Development of Welfare Levels of Transmigrants Before and After} Becoming Transmigrants

Income Level

The income received by transmigration residents is greater than before they became transmigration residents. This difference in income levels can be seen in Table 6 . below, there are 37 respondents, or $82.2 \%$, who answered yes, which means their income is higher when they have become transmigration residents when compared to before becoming transmigration residents. This higher income is due to the length of working days supported by a large number of jobs. Residents around the transmigration site who are plantation owners need the workers of transmigrants to maintain and care for their gardens.

Table 6.

The higher income of transmigrants after they join the Transmigration program

\begin{tabular}{lll}
\hline & Frequency & Percent \\
\hline Yes & 37 & \\
No & 8 & 82,2 \\
Total & 45 & 17,8 \\
\hline
\end{tabular}

Apart from the above, this higher income is also due to the transmigrants selling their crops from cultivated land, such as chillies, sweet potatoes, cassava and secondary crops or other fruits that they grow intercropping.

Employment

Most of the jobs for transmigration people are the same when they are not transmigrants and after becoming transmigrants, they become freelance workers. In terms of daily labor, the transmigrants are not always in agriculture but at construction sites and markets. Even though the type of work and wages are the same, there is a difference in the duration of the working day when compared to before becoming a transmigrant. Previously, residents only worked 10-15 days a month due to the difficulty of finding employment and the many competitors in the area of origin of the transmigrants, but after they became transmigrants, there were many jobs available around the transmigration site, which came from plantation owners around the transmigration area.

Asset ownership

Transmigrants who take part in the local transmigration program will receive assets in the form of land to be managed into a rubber plantation with an area of 1 hectare and a hectare of land used for houses and yards. In addition to the assets obtained from the government as assistance to transmigration residents, most of the residents are already able to buy goods in the form of their assets. Although not in the form of jewellery or land in other locations outside the transmigration area, the assets that they can buy on their own are motor vehicles and electronic goods that they can resell if at any time they need funds. In addition to property assets, transmigration residents also have assets in cattle managed independently by their farmer groups. 
Jurnal Manajemen Strategi dan Aplikasi Bisnis, Volume 4, Nomor. 1, 2021. 189 - 198

There are some transmigration residents who also own their own livestock, although only chickens and ducks, but these livestock can be sold and make money if there is an urgent need. From the three factors above, it shows that there has been an increase in the standard of living of the transmigration population towards prosperity. Although the calculation of the poverty level carried out in the discussion above still classifies the transmigration population into the poor category. However, this is not too much of a problem for the Mesuji Regency Government because the transmigration residents are able to continue their lives, and the transmigration residents can continue to develop and even move towards a more prosperous direction.

\section{CONCLUSIONS}

Based on the results of the research and discussion above, several conclusions can be drawn, including: First, even though they are on the poverty line, the transmigrants at UPT Fajar Baru can survive and live a more decent life by working as freelancers and farming. with seeds provided by the government; Second, the education and self-development needs of transmigrants at UPT Fajar Baru can be met through periodic assistance by the government. It aims to make it easier for the community to get a proper education and improve the ability of transmigrants.

\section{Implication}

The management of UPT Fajar Baru must pay more attention to the indicators of Communication, Resources, Disposition and Bureaucratic Structure so that coaching is more effective in the Transmigration Settlement Unit of UPT Fajar Baru, Mesuji Regency. Some of the ways that can be done include providing assistance and training for transmigrants in the economic, socio-cultural and mental-spiritual fields.

\section{Limitations}

Based on the previous description, some limitations in this study can be arranged as follows: First, the research method used is a field survey technique, which is a method that has a high dependence on the experts/surveyors used. Although there are no definite criteria for these experts. However, these limitations have been overcome by involving village officials and field implementers who know the conditions that occur in the research location; Second, the limited availability of supporting data regarding the regional profile of UPT Fajar Baru Mesuji, where no data is available with a long (time) series other than incomplete data for every aspect, especially the economy of the people living in UPT Fajar Baru Mesuji.

\section{REFERENCE}

Arman, Syamsuni. 2006. Transmigrasi dan Pluralitas. Artikel. Kompas, 18 September 2006.

Amitasari, N., Prawitasari, M., \& Akmal, H. (2021). Potret Kehidupan Masyarakat Transmigran Bali di Desa Sumber Makmur Kecamatan Satui Kabupaten Tanah Bumbu. Prabayaksa: Journal of History Education, 1(1), 1-7.

Putra, M. D., Hasan, Y., \& Safitri, S. (2019). PERKEMBANGAN EKONOMI DAN SOSIAL MASYARAKAT TRANSMIGRAN DI KOTA TERPADU MANDIRI UNIT PERMUKIMAN TERPADU SUNGAI RAMBUTAN PADA TAHUN 2008-2017 (Doctoral dissertation, Sriwijaya University).

Pradana, R. B. A. (2018). EVALUASI PROGRAM TRANSMIGRASI (STUDI KASUS PROGRAM TRANSMIGRASI DI DISTRIK KURIK, MUTING DAN SEMANGGA KABUPATEN MERAUKE. Societas: Jurnal Ilmu Administrasi dan Sosial, 7(2), 108-117. 


\section{Febriansyah \& Irwan Natakesuma}

Local transmigration, farmer welfare, poverty alleviation

Rusli, S. (2012). Pengantar Ilmu Kependudukan.[edisi revisi]. Jakarta (ID): LP3ES.

Sutanto, S. H., Aruan, N., \& HT, M. A. (2019). Evaluasi Keberhasilan Transmigran Jawa Timur di Unit Permukiman Transmigrasi Tanjung Buka SP. 3 Kabupaten Bulungan, Provinsi Kalimantan Utara. Jurnal Borneo Administrator, 15(2), 199-220.

Undang-undang Nomor 29 Tahun 2009 sebagai pengganti Undang-undang Nomor 15 tahun 1997 tentang ketransmigrasian.

Yusup, Y., \& Giyarsih, S. R. (2015). Dampak Transmigrasi terhadap Tingkat Kesejahteraan Warga Transmigran di Desa Tanjung Kukuh Kecamatan Semendawai Barat Kabuapaten Ogan Komering Ulu. Jurnal Bumi Indonesia, 4(4).

Zulhilmi, M., \& Maulana, H. (2018). Analisis pola migrasi penduduk di dataran tinggi kabupaten Aceh Tengah provinsi Aceh (Dimensi Sosial, Ekonomi, dan Infrastruktur). Jurnal Samudra Ekonomi dan Bisnis, 9(2), 104-115. 


\section{Declarations}

\section{Funding}

The authors received no financial support for the research and publication of this article.

\section{Conflicts of interest/ Competing interests:}

The authors have no conflicts of interest to declare that are relevant to the content of this article.

\section{Data, Materials, and/ or Code Availability:}

Data sharing is not applicable to this article as no new data were created or analyzed in this study.

\section{How to Cite this Article}

Febriansyah, F., \& Natakesuma, I. (2021). Implications of Transmigration Program Implementation Towards Transmigrant Welfare Levels. Jurnal Manajemen Strategi Dan Aplikasi Bisnis, 4(1), 189 - 198. https:// doi.org/ 10.36407/ jmsab.v4i1.298 